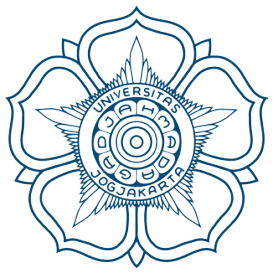

Judul Naskah

: KONTRIBUSI FATWA MAJELIS ULAMA INDONESIA NOMOR 11 TAHUN 2012 TENTANG KEDUDUKAN ANAK HASIL ZINA DAN PERLAKUAN TERHADAPNYA DALAM HUKUM KELUARGA ISLAM DI INDONESIA Nama Penulis : Haniah Ilhami

MIMBAR HUKUM

$\begin{array}{ll}\text { DOI } & : \text { http://doi.org/10.22146/jmh.29048 } \\ \text { Penerbit } & : \text { Fakultas Hukum Universitas Gadjah Mada } \\ \text { URL } & : \text { jurnal.ugm.ac.id/jmh } \\ \text { E Issn } & : 2443-0994 \\ \text { P Issn } & : 0852-100 x\end{array}$




\title{
KONTRIBUSI FATWA MAJELIS ULAMA INDONESIA NOMOR 11 TAHUN 2012 TENTANG KEDUDUKAN ANAK HASIL ZINA DAN PERLAKUAN TERHADAPNYA DALAM HUKUM KELUARGA ISLAM DI INDONESIA*
}

\author{
Haniah Ilhami** \\ Department of Islamic Law, Faculty of Law, Universitas Gadjah Mada, Yogyakarta \\ Jalan Sosio Justicia No 1 Bulaksumur, Sleman, D.I. Yogyakarta 55281
}

\begin{abstract}
Identifying the contributions of Fatwa MUI No. 1 year 2012 in Indonesian Islamic Family Law, this research finds that the Fatwa has contributed in 2 (two) positions. First, the Fatwa contributes to the development of the substance of Islamic family law through its position as the clarification and explanation of the Constitutional Court Decision Number 46/PUU-VIII/2010, as the confirmation of the prohibition of adultery, as the recommendation for the Government, and as the regulation that provides children's protection. In the other side, the Fatwa contributes practically in Religious Courts through its contribution as the Judge's guidance, completes the absence of related regulations, and the source of material law.
\end{abstract}

Keywords: children born out of wedlock, decree of the history of children, fatwa, Indonesian Council of Islamic Scholars.

\section{Intisari}

Dalam kajian terhadap Fatwa MUI No. 11 Tahun 2012, penelitian ini menemukan bahwa Fatwa MUI No.11 tahun 2012 telah memberikan kontribusi bagi hukum keluarga Islam di Indonesia dalam 2 (dua) bentuk. Pertama, fatwa berperan terhadap pengembangan substansi hukum keluarga Islam karena telah memberikan klarifikasi dan penjelasan atas Putusan MK Nomor 46/PUU-VIII/2010, mengatur larangan perbuatan zina, sebagai rekomendasi bagi Pemerintah dalam penyusunan peraturan perundang-undangan terkait zina, dan memberikan perlindungan hukum bagi anak hasil zina. Kedua, fatwa berkontribusi dalam tataran praktis di Pengadilan Agama sebagai pedoman Hakim, pengisi kekosongan hukum, dan sebagai sumber hukum materiil.

Kata Kunci: anak hasil zina, penetapan asal-usul anak, fatwa, Majelis Ulama Indonesia.

\section{Pokok Muatan}

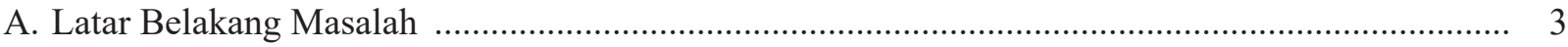

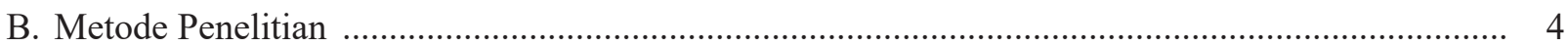

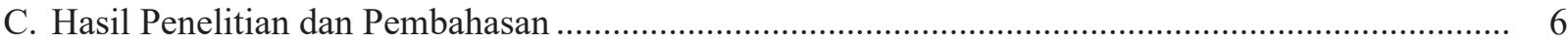

1. Kontribusi Fatwa MUI No. 11 Tahun 2012 dalam Pengembangan Substansi Hukum Keluarga

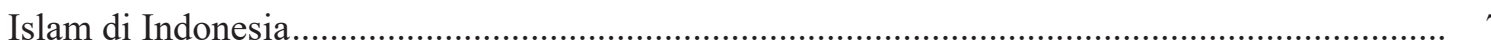

2. Kontribusi Fatwa MUI No. 11 Tahun 2012 sebagai Pertimbangan Hakim dalam Putusan Bidang Perkawinan di Pengadilan Agama ......................................................................... 12

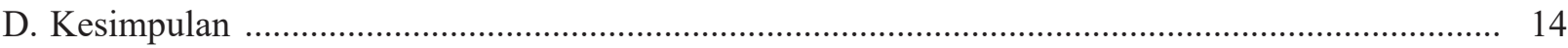

Hasil Penelitian yang didanai oleh Unit Riset dan Publikasi Fakultas Hukum Universitas Gadjah Mada pada tahun 2016. Penelitian dilaksanakan untuk mengikuti Program Penelitian Dosen Master Fakultas Hukum Universitas Gadjah Mada.

***ail korespondensi:haniah.ilhami@gmail.com. 


\section{A. Latar Belakang Masalah}

Fatwa Majelis Ulama Indonesia No. 11 Tahun 2012 tentang Kedudukan Anak Hasil Zina dan Perlakuan Terhadapnya (selanjutnya disebut Fatwa MUI No. 11 Tahun 2012) adalah respon dari Majelis Ulama Indonesia (selanjutnya disebut MUI) atas Putusan Mahkamah Konstitusi No. 46/ PUU-VIII/2010 (selanjutnya disebut Putusan MK No.46/PUU-VIII/ 2010) yang melahirkan banyak kontroversi dan pertanyaan di masyarakat. ${ }^{1}$ Bermula dari norma hukum baru yang ditetapkan Mahkamah dalam putusannya bahwa anak yang dilahirkan di luar perkawinan dapat mempunyai hubungan perdata dengan laki-laki sebagai ayahnya dan keluarga ayahnya sepanjang dibuktikan berdasarkan ilmu pengetahuan dan teknologi dan/atau alat bukti lain menurut hukum bahwa keduanya mempunyai hubungan darah, ${ }^{2}$ pendapat masyarakat terbelah menjadi 2 (dua) kelompok.

Kelompok pertama mendukung putusan ini dengan alasan bahwa Putusan MK No.46/PUUVIII/ 2010 ini merupakan terobosan hukum yang progresif dalam melindungi hak-hak konstitusional anak. ${ }^{3}$ Sementara bagi kelompok kedua yang menolak putusan MK, termasuk di antaranya MUI, menilai bahwa putusan ini tidak sesuai dengan hukum Islam, melanggar tujuan hukum dan aturan hukum perkawinan, serta rentan dimanfaatkan untuk melegalkan perzinahan. ${ }^{4}$ Tidak lama setelah diputuskan, ketua MUI menyatakan bahwa Putusan MK No.46/PUU-VIII/ 2010 telah melampaui permohonan yang semula sekedar menghendaki pengakuan keperdataan atas anak dengan bapak hasil perkawinan tapi tidak dicatatkan kepada KUA menjadi meluas mengenai hubungan keperdataan atas anak hasil hubungan zina dengan lelaki yang mengakibatkan kelahirannya. ${ }^{5}$

Lahirnya kontroversi terhadap Putusan MK No.46/PUU-VIII/ 2010 ini bermula dari penggunaan terminologi "anak yang dilahirkan di luar perkawinan" yang tidak pernah didefinisikan secara jelas baik dalam Undang-undang No. 1/1974 maupun Putusan MK No.46/PUU-VIII/ 2010 itu sendiri. Sebagai usaha untuk menafsirkannya, praktisi dan akademisi hukum menggunakan ketentuan tentang syarat sah dan kewajiban pencatatan perkawinan yang diatur dalam UndangUndang No. 1 tahun 1974 tentang Perkawinan dan dikuatkan kembali melalui Instruksi Presiden No. 1 tahun 1991 tentang Penyebarluasan Kompilasi Hukum Islam. ${ }^{6}$ Melalui kedua ketentuan tersebut, terminologi "anak yang dilahirkan di luar perkawinan" dapat dikelompokkan ke dalam 2 (dua) kelompok, yaitu anak yang lahir dari perkawinan tidak tercatat dan anak yang lahir tanpa perkawinan. ${ }^{7}$ Dari kedua kelompok anak tersebut, kontroversi muncul terhadap kelompok yang kedua, yaitu anak yang lahir tanpa perkawinan atau dikenal sebagai anak hasil zina.

Anak hasil zina, dalam ketentuan fiqh Islam, hanya akan memiliki hubungan nasab dengan ibu yang melahirkannya saja. Dikaitkan dengan pengakuan hak keperdataan anak yang lahir di luar perkawinan melalui Putusan MK No.46/PUU-VIII/ 2010, masyarakat beranggapan bahwa putusan dimaksud telah menempatkan anak hasil zina setara dengan anak yang lahir dari perkawinan yang sah. Lebih jauh lagi, Putusan MK No.46/PUU-VIII/ 2010 juga dianggap telah melegalisasi secara tidak langsung perbuatan zina yang merupakan perbuatan

\footnotetext{
Lihat Bagian Pertimbangan Fatwa Majelis Ulama Indonesia Nomor 11 Tahun 2012 tentang Kedudukan Anak Hasil Zina dan Perlakuan Terhadapnya.

Amar Putusan Mahkamah Konstitusi No. 46/PUU-VIII/2010.

Siti Musawwamah, "Pro-kontra atas Putusan Mahkamah Konstitusi tentang Pengesahan Hubungan Keperdataan Anak Luar Kawin dengan Ayah Biologis", Nuansa, Vol.10, No.1, Januari-Juni, 2013.

Ibid.

Detiknews, "MUI Nilai Keputusan MK Soal Status Anak di Luar Nikah Overdosis", http://news.detik.com/berita/1866192/mui-nilaikeputusan-mk-soal-status-anak-di-luar-nikah-overdosis, diakses 24 Maret 2017.

Lihat Pasal 2 Undang-Undang Nomor 1 Tahun 1974 tentang Perkawinan (Lembaran Negara Republik Indonesia Tahun 1974 Nomor 1, Tambahan Lembaran Negara Nomor 3019) dan Pasal 5 dan 6 Kompilasi Hukum Islam.

IKAHI Cabang Pengadilan Tinggi Agama Semarang,'"Rumusan Hasil Diskusi tentang Kedudukan Anak yang Lahir di Luar Perkawinan pasca Putusan MK Nomor 46/PUU-VIII/2010 tanggal 17 Februari 2012”, Makalah Rumusan Hasil Diskusi, Diskusi IKAHI Cabang Pengadilan Tinggi Agama Semarang, Semarang, Rabu 11 April 2012.
} 
tercela dan melanggar norma agama dan kesusilaan.

Pertanyaan ini dijawab oleh MUI melalui Fatwa MUI No. 11 Tahun 2012 tentang Kedudukan Anak Hasil Zina dan Perlakuan Terhadapnya guna meluruskan persepsi masyarakat dan mengatur kedudukan anak hasil zina sesuai ketentuan hukum Islam. Fatwa MUI No. 11 Tahun 2012 secara tegas menyatakan bahwa anak hasil zina tidak mempunyai hubungan nasab, wali nikah, waris, dan nafaqah dengan lelaki yang mengakibatkan kelahirannya. ${ }^{8}$ Namun di saat yang sama, sebagai bentuk perlindungan terhadap hak yang dimiliki anak hasil zina, fatwa juga menetapkan tentang kewenangan pemerintah untuk menjatuhkan hukuman ta'zir kepada lelaki pezina yang mengakibatkan lahirnya anak dalam 2 (dua) bentuk, yaitu: ${ }^{9}$ pertama, mewajibkan lelaki pezina untuk mencukupi kebutuhan hidup anak; kedua, memberikan bagian dari harta peninggalan lelaki pezina pada anak yang lahir akibat perbuatan zinanya tersebut melalui mekanisme wasiat wajibah. Melalui fatwa ini, MUI juga telah melahirkan norma baru tentang kedudukan hukum anak yang lahir tanpa perkawinan atau anak hasil zina.

Kondisi tersebut di atas menjadi fokus permasalahan yang dijawab melalui penelitian ini. Peneliti mengkaji tentang kedudukan Fatwa MUI No. 11 Tahun 2012 dalam Hukum Keluarga Islam di Indonesia. Secara komprehensif, penelitian ini mengangkat permasalahan tentang kedudukan Fatwa MUI No. 11 Tahun 2012 dari 2 (dua) bidang, yaitu kedudukannya dalam ranah kajian teoritis hukum keluarga Islam dan dalam ranah praktis di wilayah sistem peradilan agama di Indonesia.

\section{B. Metode Penelitian}

Penelitian ini merupakan penelitian hukum normatif yang dilakukan melalui kajian terhadap peraturan-peraturan hukum tertulis atau bahanbahan hukum yang ada. Penelitian dilengkapi dengan penelitian lapangan melalui Focus Group Discussion yang melibatkan narasumber dan responden terkait guna memperdalam jawaban atas masalah yang telah ditemukan dalam tahap sebelumnya. Penelitian kepustakaan dilakukan dalam 2 (dua) tahap, sebelum penelitian lapangan dan setelah penelitian lapangan dilakukan. Peneliti melakukan kajian terhadap data sekunder, meliputi dokumen-dokumen hukum resmi, hasil penelitian terdahulu, dan bahan-bahan pustaka lainnya dalam tahap tersebut. Berkaitan dengan dokumen hukum resmi, peneliti melakukan kajian terhadap bahan hukum primer yang bersifat mengikat dan berhubungan erat dengan pemasalahan yang diteliti, meliputi 2 (dua) kelompok yaitu:

1. Peraturan perundang-undangan, terdiri dari:

a. Undang-Undang Nomor 1 Tahun 1974 tentang Perkawinan (Lembaran Negara Republik Indonesia Tahun 1974 Nomor 1, Tambahan Lembaran Negara Nomor 3019);

b. Undang-Undang Nomor 7 Tahun 1989 tentang Peradilan Agama (Lembaran Negara Republik Indonesia Tahun 1989 Nomor 49, Tambahan Lembaran Negara Nomor 3400);

c. Undang-Undang Nomor 4 Tahun 2004 tentang Kekuasaan Kehakiman (Lembaran Negara Republik Indonesia Tahun 2004 Nomor 8, Tambahan Lembaran Negara Republik Indonesia Nomor 4358);

d. Undang-Undang Nomor 48 Tahun 2009 tentang Kekuasaan Kehakiman (Lembaran Negara Republik Indonesia Tahun 2009 Nomor 157, Tambahan Lembaran Negara Republik Indonesia Nomor 5076);

e. Undang-Undang Nomor 


\begin{tabular}{|c|c|}
\hline & $12 \quad$ Tahun 2011 \\
\hline & Pembentukan \\
\hline & P e rund ang-und ang a n \\
\hline & (Lembaran Negara Nomor \\
\hline & 82 Tahun 2011, Tambahan \\
\hline & Negara Nomor \\
\hline & 5234); \\
\hline f. & Undang-Undang \\
\hline & 23 Tahun 2002 \\
\hline & Perlindungan Anak (Lembaran \\
\hline & Negara Nomor 109 Tahun 2002, \\
\hline & Tambahan Lembaran Negara \\
\hline & Nomor 4235); \\
\hline g. & Undang-Undang Nomor 35 \\
\hline & Tahun 2014 tentang Perubahan \\
\hline & atas Undang-Undang Nomor \\
\hline & 23 Tahun \\
\hline & Perlindungan Anak (Lembaran \\
\hline & Negara Nomor 297 Tahun 2014, \\
\hline & Tambahan Lembaran Negara \\
\hline & Nomor 5606); \\
\hline h. & Undang-Undang Nomor 23 \\
\hline & Tahun 2006 tentang Administrasi \\
\hline & Kependudukan \\
\hline & Negara Nomor 124 Tahun 2006, \\
\hline & Tambahan Lembaran Negara \\
\hline & Nomor 4674); \\
\hline i. & Undang-Undang \\
\hline & Tahun 2013 tentang Perubahan \\
\hline & atas Undang-Undang Nomor \\
\hline & 23 Tahun \\
\hline & Administrasi Kependudukan \\
\hline & (Lembaran \\
\hline & 232 Tahun 2013, Tambahan \\
\hline & Negara Nomor \\
\hline & $5475)$ \\
\hline J. & Instruksi Presiden \\
\hline & Indonesia Nomor 1 Tahun \\
\hline & 1991 tentang Penyebarluasan \\
\hline & Kompilasi Hukum \\
\hline & (Lembaran Lepas Sekretaria \\
\hline & Negara Tahun 1991 \\
\hline
\end{tabular}

2. Keputusan Pejabat Administratif, Surat Keputusan, Surat Edaran,
Putusan Pengadilan, dan bahan hukum mengikat lainnya, terdiri dari:

a. Kitab Undang-Undang Hukum Perdata;

b. Kitab Undang-Undang Hukum Pidana;

c. Peraturan Menteri Dalam Negeri Nomor 9 Tahun 2016 tentang Percepatan Peningkatan Cakupan Kepemilikian Akta Kelahiran;

d. Surat Edaran Kepala Biro peradilan Agama Departemen Agama RI No. B/I/735 tentang Pelaksanaan Peraturan Pemerintah No. 45 Tahun 1957 tentang Pembentukan Pengadilan Agama/Mahkamah Syar'iyah di Luar Jawa-Madura;

e. Peraturan Ketua Mahkamah Agung Nomor KMA/032/SK/ IV/2006 tentang Pemberlakuan Buku II Pedoman Pelaksanaan Tugas dan Administrasi Peradilan Agama;

f. Surat Edaran Ketua Muda Agama (TUADA) Nomor 14/ TUADA-AG/IX/2013 tentang Petunjuk Teknis Buku II Edisi Revisi Tahun 2013;

g. Fatwa Majelis Ulama Indonesia Nomor 11 Tahun 2012 tentang Kedudukan Anak Hasil Zina dan Perlakuan Terhadapnya ;

h. Fatwa MUI Nomor 10 Tahun 2008 tentang Nikah Bawah Tangan;

i. Peraturan Organisasi Majelis Ulama Indonesia tentang Pedoman Penetapan Fatwa Majelis Ulama Indonesia;

j. Putusan Mahkamah Konstitusi No. 46/PUU-VIII/2010;

k. Putusan Mahkamah Agung 
No.93 K/Kr/1976;

1. Putusan Pengadilan Agama

Sleman Nomor 0870/

Pdt.G/2014/PA. Slm;

m. Penetapan Pengadilan Agama

Jakarta Selatan Nomor 190/

Pdt.P/2016/PAJS;

n. Penetapan Pengadilan Agama

Kediri Nomor 0005/Pdt.P/2016/

PA.Kdr;

o. Penetapan Pengadilan Agama

Jakarta Selatan Nomor 0156/

Pdt.P/2013/PA JS.

Penelitian terhadap data sekunder tersebut kemudian dilengkapi melalui kegiatan Focus Group Discussion dengan mengundang beberapa narasumber dan responden. Narasumber yang hadir dalam kegiatan ini adalah Bapak KRT. Drs.H. Ahmad Muhsin Kamaludiningrat sebagai perwakilan MUI D.I. Yogyakarta, dan responden sebagai berikut:

1. Bapak Drs. H. Nashruddin Salim, S.H., M.M., sebagai Hakim Pengadilan Agama Yogyakarta;

2. Ibu Ummu Hafizhah, S.H.I, S.E., M.A., sebagai Hakim Pengadilan Agama Wates;

3. Ibu Latifah Setyawati, S.H., M.Hum., sebagai Hakim Pengadilan Agama Bantul

Dari hasil penelitian lapangan tersebut, analisis atas hasil Focus Group Discussion dilakukan dengan cara data yang diperoleh langsung diolah dan dianalisis secara deskriptif kualitatif. Proses analisis ini dilaksanakan dan dijabarkan dalam sebuah deskripsi yang luas sehingga proses ketika mendeskripsikan data secara bersamaan juga berlangsung proses analisis.

\section{Hasil Penelitian dan Pembahasan}

Fatwa MUI secara umum adalah jawaban atau penjelasan dari ulama mengenai masalah keagamaan dan berlaku untuk umum. ${ }^{10}$ Dalam tata urutan peraturan peruundangan-undangan di Indonesia, Fatwa MUI tidak ditempatkan sebagai bagian dari hierarki peraturan perundang-undangan. Oleh karena itu, fatwa MUI dianggap sebagai instrumen hukum yang sifatnya tidak mengikat dan tidak ada paksaan secara hukum untuk mematuhinya. Namun demikian, dalam catatan sejarah Fatwa MUI banyak digunakan sebagai pedoman dan prinsip-prinsip pengembangan hukum ketika proses pembentukan peraturan perundang-undangan ${ }^{11}$ Secara formal, pada tataran praktis peradilan, Fatwa MUI ditetapkan untuk menjadi salah satu hukum materiil untuk digunakan oleh hakim di Pengadilan Agama $^{12}$ Selain itu, dinamika internal lingkungan peradilan agama saat ini berusaha mendorong lahirnya putusan-putusan hakim yang bermutu dengan ditandai antara lain bahwa putusan tersebut harus mengandung pembaruan hukum Islam $^{13}$ Melalui usaha pembaruan hukum Islam ini, maka putusan hakim harus berpijak pada prinsip-prinsip dasar syariah yang dikembangkan melalui asasasas hukum Islam baik yang bersifat umum maupun khusus. ${ }^{14}$ Oleh karena itu, hakim didorong untuk menggali, memahami dan mengikuti nilai-nilai hukum dan keadilan dalam masyarakat, termasuk di dalamnya menggunakan Fatwa MUI sebagai salah satu pedoman hukum Islam dalam masyarakat.

Berkaitan dengan hal-hal tersebut di atas, penelitian ini menemukan bahwa Fatwa MUI No.11 tahun 2012 memiliki 2 (dua) kontribusi penting dalam sistem hukum keluarga islam di Indonesia secara umum, yaitu dalam ranah kajian teoritis dan dalam ranah praktis di Pengadilan Agama. Dalam ranah kajian teoritis, Fatwa MUI No.11 tahun 2012 berkontribusi pada proses pengembangan hukum

\footnotetext{
Pasal 1 Angka 7 Peraturan Organisasi Majelis Ulama Indonesia tentang Pedoman Penetapan Fatwa Majelis Ulama Indonesia.

11 Wahiduddin Adams, 2004, Pola Penyerapan Fatwa Majelis Ulama Indonesia (MUI) dalam Peraturan Perundang-undangan 1975-1997, Departemen Agama Republik Indonesia, Jakarta, hlm. 590.

12 Mahkamah Agung, 2013, Pedoman Pelaksanaan Tugas dan Administrasi Peradilan Agama Buku II, Dirjen Peradilan Agama Mahkamah Agung, Jakarta, hlm. 65.

Mukti Arto, 2015, Pembaruan Hukum Islam melalui Putusan Hakim, Pustaka Pelajar, Yogyakarta, hlm. 3.

14 Ibid., hlm. 10.
} 
keluarga Islam di Indonesia melalui penetapan norma tentang status dan kedudukan anak yang lahir dari perbuatan zina yang komprehensif dan solutif. Sementara dalam kedudukannya pada ranah praktis, Fatwa MUI No.11 Tahun 2012 digunakan sebagai sebagai pertimbangan hakim dalam merumuskan produk hukum yang berkeadilan.

Secara rinci, kedudukan Fatwa MUI No.11 Tahun 2012 dalam hukum keluarga Islam di Indonesia tersebut dijelaskan sebagai berikut.

\section{Kontribusi Fatwa MUI No. 11 Tahun 2012 dalam Pengembangan Substansi Hukum Keluarga Islam di Indonesia}

Pada awalnya, perumusan Fatwa MUI No.11 Tahun 2012 hanya dimaksudkan untuk merespon Putusan MK Nomor 46/PUU-VIII/2010 yang dianggap telah menimbulkan pertanyaan di masyarakat tentang status hukum bagi anak yang lahir di luar perkawinan dalam perspektif hukum Islam $^{15}$. Namun apabila melihat pada rumusan norma yang diatur dalam Fatwa MUI No.11 Tahun 2012, peneliti berkesimpulan bahwa Fatwa MUI No.11 Tahun 2012 telah kontribusi dalam pengembangan substansi hukum keluarga Islam dalam bentuk sebagai berikut $:^{16}$

a. Fatwa MUI No. 11 Tahun 2012 sebagai Klarifikasi dan Penjelasan atas Putusan MK Nomor 46/PUUVIII/2010

Putusan MK Nomor 46/PUUVIII/2010 telah melahirkan norma baru tentang hubungan hukum antara anak yang lahir di luar perkawinan dengan bapak biologisnya, dengan menyatakan bahwa di antara keduanya bisa lahir hubungan keperdataan sepanjang telah dibuktikan adanya hubungan darah melalui caracara tertentu. Berdasarkan sudut pandang hukum Islam, Putusan MK Nomor 46/PUU-
VIII/2010 ini menimbulkan perdebatan tentang kedudukan anak yang lahir dari luar perkawinan atau dikenal dengan anak hasil zina. Putusan MK Nomor 46/PUU-VIII/2010 dianggap telah mengaburkan status hukum dan kedudukan kelompok anak yang lahir dari hubungan zina. Apabila sebelumnya melalui KHI sudah ditegaskan bahwa anak yang lahir di luar perkawinan hanya mempunyai hubungan nasab dengan ibunya dan keluarga ibunya, ${ }^{17}$ maka Putusan MK Nomor 46/PUU-VIII/2010 bertolak belakang dengan ketentuan tersebut. ${ }^{18}$ Terlebih lagi, dalam ketentuan hukum Islam, anak yang lahir dari perbuatan zina secara tegas tidak bisa memiliki hubungan nasab dengan bapak biologisnya, sekalipun telah dibuktikan ada hubungan darah di antara keduanya. Dampak dari lahirnya norma baru pada Putusan MK Nomor 46/PUU-VIII/2010 telah melahirkan pendapat dalam masyarakat bahwa Putusan MK ini melegalkan status hukum antara anak hasil zina dengan bapak biologisnya.

Klarifikasi atas Putusan MK Nomor 46/PUU-VIII/2010 melalui Fatwa No. 11 Tahun 2011 dalam dilihat dalam bagian pertimbangan Fatwa dimaksud sebagai berikut:

$[\ldots]$

c. bahwa terhadap masalah tersebut, Mahkamah Konsitusi dengan pertimbangan memberikan perlindungan kepada anak dan memberikan hukuman atas laki-laki yang menyebabkan kelahirannya untuk bertanggung jawab, menetapkan putusan MK Nomor 46/PUU-VIII/2010 yang pada intinya mengatur kedudukan anak yang dilahirkan di luar perkawinan mempunyai

\footnotetext{
15 Lihat Pertimbangan huruf (c) Fatwa Majelis Ulama Indonesia Nomor 11 Tahun 2012 tentang Kedudukan Anak Hasil Zina dan Perlakuan Terhadapnya

16 Disimpulkan dari pendapat KRT. Drs.H., Ahmad Muhsin Kamaludiningrat, Drs.H. Nashruddin Salim, S.H., M.H., Ummu Hafizhah, S.H.I., S.E., M.A., dan Latifah Setyawati, S.H., M.Hum. pada Focus Group Discussion di Yogyakarta, 27 Mei 2017.

Pasal 100 Kompilasi Hukum Islam.

18 Pendapat KRT. Drs.H., Ahmad Muhsin Kamaludiningrat pada Focus Group Discussion di Yogyakarta, 27 Mei 2017.
} 
hubungan perdata dengan ibunya dan keluarga ibunya serta dengan laki-laki sebagai ayahnya yang dapat dibuktikan berdasarkan ilmu pengetahuan dan teknologi dan/atau alat bukti lain menurut hukum mempunyai hubungan darah, termasuk hubungan perdata dengan keluarga ayahnya;

d. bahwa terhadap putusan tersebut, muncul pertanyaan dari masyarakat mengenai kedudukan anak hasil zina, terutama terkait dengan hubungan nasab, waris, nafaqah dan wali nikah dari anak hasil zina dengan laki-laki yang mengakibatkan kelahirannya menurut hukum Islam;

e. bahwa oleh karena itu dipandang perlu menetapkan fatwa tentang kedudukan anak hasil zina dan perlakuan terhadapnya guna dijadikan pedoman. ${ }^{19}$

Melihat pada kutipan tersebut di atas, maka secara khusus Fatwa MUI No. 11 Tahun 2012 memang menempatkan posisi sebagai klarifikasi atas ketentuan Putusan MK Nomor 46/PUU-VIII/2010.

\section{b. Fatwa MUI No. 11 Tahun 2012 \\ sebagai Penegasan Larangan \\ Berzina}

Perbuatan zina dalam sistem hukum pidana di Indonesia memiliki definisi berbeda bila dibandingkan dengan ketentuan hukum Islam. Kitab Undang-undang Hukum Pidana (KUHP) hanya membatasi perbuatan zina dalam bentuk persetubuhan di antara orang yang masih terikat perkawinan dengan suami/atau istri sahnya. ${ }^{20}$ Lebih lanjut, KUHP menempatkan perbuatan zina sebagai delik aduan yang memiliki dimensi domestik, mengingat proses hukum terhadap perbuatan tersebut hanya dapat dimulai bila telah ada aduan dari suami/istri sah dari pasangan sah orang yang melakukan zina tersebut. Hal berbeda ditemukan dalam perspektif hukum Islam. Zina dalam Islam adalah hubungan biologis di antara orang yang tidak terikat perkawinan dan hukumnya adalah haram. Hukuman atas perbuatan zina tidak tergantung pada adanya aduan dari suami/ istri yang sah. Perbedaan konsep perbuatan zina ini menunjukkan adanya pertentangan yang mendasar antara ketentuan zina berdasarkan sistem hukum pidana Indonesia dengan hukum Islam.

Fatwa MUINo.11 Tahun 2012 memberi penegasan tentang perbuatan zina dari sudut pandang hukum Islam. Fatwa MUI No. 11 Tahun 2012 menegaskan bahwa zina adalah tindak pidana kejahatan (jarimah) yang terhadapnya berlaku ketentuan hadd yaitu ancaman hukuman yang telah ditentukan dalam nash/dalil Al-quran dan sunnah. Sebagai bentuk kejahatan, perbuatan jarimah secara umum diancam dengan hukuman tertentu guna melindungi kepentingan kolektif masyarat, sekaligus menyelamatkan nilai-nilai moral yang menjadi pedoman dalam hidup bermasyarakat ${ }^{21}$ Khusus untuk perbuatan zina, hukum Islam menetapkan hukuman rajam atau cambuk pada pelakunya setelah memenuhi beban pembuktian yang ditentukan. Secara rinci, penegasan tersebut dapat dilihat dalam kutipan berikut ${ }^{22}$ :

[...]Anak hasil zina adalah anak yang lahir sebagai akibat dari hubungan badan di luar pernikahan yang sah menurut ketentuan agama, dan merupakan jarimah (tindak pidana kejahatan).

\footnotetext{
Lihat Bagian Menimbang Fatwa MUI Nomor 11 Tahun 2012.

Lihat Pasal 284 KUHP.

21 Topo Santoso, 2003, Membumikan Hukum Pidana Islam di Indonesia Penegakan Syariat dalam Wacana dan Agenda, Gema Insani Press, Jakarta, hlm. 22.

22 Ketentuan Umum angka (1) Fatwa Majelis Ulama Indonesia Nomor 11 Tahun 2012 tentang Kedudukan Anak Hasil Zina dan Perlakuan Terhadapnya.
} 
Penegasan juga dilakukan terhadap bentuk hukuman yang dijatuhkan pada pelaku zina. Dalam fatwa MUI No.11 Tahun 2012, secara jelas ditegaskan bahwa pezina dikenakan hukuman hadd oleh pihak yang berwenang, untuk kepentingan menjaga keturunan yang sah (hifzh alnasl). ${ }^{23}$ Tidak hanya memberikan penegasan tentang hukuman hadd saja, fatwa MUI No.11 Tahun 2012 juga mengatur hukuman tambahan berupa ta'zir yang wewenang penjatuhannya diserahkan sepenuhnya pada pemerintah. ${ }^{24}$ Ta'zir adalah jenis hukuman atas tindak pidana yang bentuk dan kadarnya diserahkan kepada ulil amri (pihak yang berwenang menetapkan hukuman). ${ }^{25}$ Bentuk hukuman ta'zir bagi pelaku zina dalam fatwa ini adalah melalui perintah bagi pelaku zina untuk mencukupi kebutuhan hidup anak yang lahir dari hubungan zina dan memberikan harta setelah pelaku zina meninggal dunia melalui wasiat wajibah. Melalui penambahan ini, fatwa MUI No.11 Tahun 2012 semakin memperkuat penegasan perbuatan zina sebagai bentuk kejahatan yang dilarang dan terhadapnya diancam hukuman yang berat.

\section{c. Fatwa MUI No. 11 Tahun 2012 sebagai Rekomendasi bagi Pemerintah}

Fatwa MUI No.11 Tahun 2012 secara umum memang bertujuan untuk menjelaskan tentang kedudukan dan status hukum anak yang lahir dari perbuatan zina. Namun demikian, Fatwa MUI ini juga disusun secara komprehensif dengan ikut memasukkan usulan solusi dari lembaga MUI kepada pemerintah untuk menghadapi perbuatan zina yang terjadi di masyarakat yang disusun dalam bentuk rekomendasai sebagai bagian integral dari fatwa MUI No.11 tahun 2012 ini. Dalam rekomendasinya, MUI meminta agar DPR-RI dan Pemerintah segera menyusun peraturan perundang-undangan yang mengatur hukuman berat terhadap pelaku perzinaan serta memasukkan zina yang selama ini hanya merupakan delik aduan menjadi delik umum karena zina merupakan kejahatan yang menodai martabat luhur manusia. ${ }^{26}$ Lebih jauh lagi, fatwa MUI No.11 Tahun 2012 juga memberikan rekomendasai edukatif agar pemerintah mengedukasi masyarakat untuk tidak memperlakukan anak yang lahir dari perbuatan zina secara diskriminatif. Pemberian rekomendasi ini manunjukkan bahwa fatwa MUI No. 11 /2012 tidak hanya sekedar menetapkan norma hukum atas perbuatan zina untuk jangka pendek saja, namun juga memberikan solusi jangka panjang untuk menurunkan tingkat perbuatan zina di masyarakat luas.

\section{d. Fatwa MUI No. 11 Tahun 2012 sebagai Perlindungan bagi Anak Hasil Zina}

Perlindungan anak adalah segala kegiatan untuk menjamin dan melindungi anak dengan hak-haknya agar dapat hidup, tumbuh, berkembang, dan berpartisipasi secara optimal sesuai harkat dan martabat kemanusiaan serta mendapat perlindungan dari kekerasan dan diskriminasi. ${ }^{27}$ Sebagai bentuk tanggung jawab negara, maka

\footnotetext{
23 Ketentuan Hukum angka (4) Fatwa Majelis Ulama Indonesia Nomor 11 Tahun 2012 tentang Kedudukan Anak Hasil Zina dan Perlakuan Terhadapnya.

24 Ketentuang Hukum angka (5) Fatwa Majelis Ulama Indonesia Nomor 11 Tahun 2012 tentang Kedudukan Anak Hasil Zina dan Perlakuan Terhadapnya.

25 Ketentuan Umum angka (3) Fatwa Majelis Ulama Indonesia Nomor 11 Tahun 2012 tentang Kedudukan Anak Hasil Zina dan Perlakuan Terhadapnya.

26 Rekomendasi angka (1) Fatwa Majelis Ulama Indonesia Nomor 11 Tahun 2012 tentang Kedudukan Anak Hasil Zina dan Perlakuan Terhadapnya.

27 Pasal 1 angka 2 Undang-Undang Nomor 23 Tahun 2002 tentang Perlindungan Anak (Lembaran Negara Nomor 109 Tahun 2002, Tambahan Lembaran Negara Nomor 4235) sebagaimana yang telah diubah oleh Undang-Undang Nomor 35 Tahun 2014 tentang Perubahan atas Undangundang Nomor 23 Tahun 2002 tentang Perlindungan Anak (Lembaran Negara Nomor 297 Tahun 2014, Tambahan Lembaran Negara Nomor 5606).
} 
perlindungan anak diberikan melalui jaminan hak-hak anak secara menyeluruh. Orang tua, negara dan masyarakat berkewajiban dan bertanggungjawab.$^{28}$

Perlindungan anak dalam perspektif hukum Islam, dilakukan dalam 3 (tiga) dimensi hak anak, yaitu: ${ }^{29}$ pertama, perlindungan bibit anak, yang dilakukan antara lain dengan larangan perkawinan antara 2 (dua) orang yang memiliki hubungan darah; kedua, perlindungan kelangsungan hidup, kesejahteraan, dan masa depan anak melalui ketentuan tanggung jawab orang tua kepada anaknya; ketiga, perlindungan legalitas dan nasab anak, yang dilakukan melalui ketentuan syarat sah perkawinan melalui akad nikah dan memiliki akta nikah. Perlindungan ketiga dimensi tersebut merupakan salah satu tanggung jawab negara dalam rangka mewujudkan hak kemanusiaan yang asasi bagi anak.

Berkaitan dengan perlindungan anak, fatwa MUI No.11 Tahun 2012 mengatur secara tegas kedudukan dan hubungan hukum untuk anak yang lahir dari perbuatan zina antara ibu yang melahirkannya dengan laki-laki yang menyebabkan kelahirannya tersebut dalam 2 (dua) hal, yaitu: ${ }^{30}$

1) Anakhasil zinatidak mempunyai hubungan nasab, wali nikah, waris, dan nafaqah dengan lelaki yang mengakibatkan kelahirannya.

2) Anak hasil zina hanya mempunyai hubungan nasab, waris, dan nafaqah dengan ibunya dan keluarga ibunya.

Berdasarkan ketentuan tersebut, terlihat pembatasan hubungan hukum antara anak yang lahir dari perbuatan zina dengan laki-laki yang menyebabkan kelahirannya sebagai bentuk penegakan hukum Islam yang memang secara tegas mengatur pembatasan tersebut. Pembatasan tidak bertujuan untuk mendiskriminasi hubungan sosial antara anak yang lahir dari hubungan zina dengan kedua orang tuanya dan dengan lingkungan sekitarnya, melainkan hanya untuk melindungi nasab anak dan ketentuan keagamaan lain yang terkait dengan nasab tersebut. Melalui pembatasan ini, fatwa MUI meluruskan kedudukan hukum anak hasil zina agar tidak muncul penafsiran keliru di masyarakat khususnya pasca Putusan MK No. 46/PUU-VIII/2010.

Pada saat yang sama, fatwa MUI No.11 tahun 2012 justru memberikan perlindungan hukum kepada anak yang lahir dari perbuatan zina secara lebih tegas dan komprehensif terutama bila dibandingkan dengan ketentuan dalam Putusan MK No. 46/PUU-VIII/2010. Apabila Putusan MK No. 46/PUU-VIII/2010 hanya menegaskan lahirnya hubungan perdata antara anak yang lahir di luar perkawinan dengan kedua orang tua biologisnya tanpa merinci bentuk dan jenis hubungan tersebut, fatwa MUI No.11 Tahun 2012 memberikan perlindungan hukum dari beberapa aspek sekaligus bagi anak yang lahir dari perbuatan zina, yaitu:

1) Perlindungan Hukum bagi Anak Hasil Zina selama LakiLaki yang Menyebabkan Kelahirannya Masih Hidup : Fatwa MUI No. 11 Tahun 2012 menegaskan perlindungan hukum bagi anak hasil zina dengan memberikan kewenangan pada pemerintah untuk

\footnotetext{
28 Pasal 20 Undang-Undang No. 23 Tahun 2002 tentang Perlindungan Anak sebagaimana yang telah diubah oleh Undang-Undang Nomor 35 Tahun 2014 tentang Perubahan atas Undang-Undang Nomor 23 Tahun 2002 tentang Perlindungan Anak (Lembaran Negara Nomor 297 Tahun 2014, Tambahan Lembaran Negara Nomor 5606).

29 Mukti Arto, 2017, Penemuan Hukum Islam Demi Mewujudkan Keadilan Buku Kesatu Membangun Sistem Peradilan Berbasis Perlindungan Hukum dan Keadilan, Pustaka Pelajar, Yogyakarta, hlm. 169.

30 Ketentuan hukum angka (1) dan (2) Fatwa Majelis Ulama Indonesia Nomor 11 Tahun 2012 tentang Kedudukan Anak Hasil Zina dan Perlakuan Terhadapnya.
} 
menjatuhkan hukuman ta'zir berupa kewajiban bagi laki-laki yang menyebabkan kelahirannya untuk mencukupi kebutuhan hidup anak. ${ }^{31}$ Penjatuhan hukuman ta'zir dapat dilakukan melalui putusan hakim Pengadilan Agama atas permohonan penetapan asal usul anak. Melalui hukuman ta'zir ini, maka anak dapat menuntut hak nafkah dari laki-laki yang menyebabkan kelahirannya selama beliau masih hidup. Hal ini dapat dilihat pada bagian Fatwa No. 11 Tahun 2012 berikut: ${ }^{32}$

Pemerintah berwenang menjatuhkan hukuman ta'zir kepada lelaki pezina yang mengakibatkan lahirnya anak dengan mewajibkannya untuk :

a. mencukupi kebutuhan hidup anak tersebut;

$[\ldots]$

2) Perlindungan Hukum bagi Anak Hasil Zina Setelah LakiLaki yang Menyebabkan Kelahirannya Meninggal Dunia :

Perlindungan hukum terhadap anak hasil zina tidak sebatas hanya selama laki-laki yang menyebabkan kelahirannya masih hidup saja. Fatwa MUI secara progresif memberikan perlindungan hukum setelah kedua orang tua yang menyebabkan kelahiran anak zina meninggal dunia melalui kewenangan pada pemerintah untuk menjatuhkan hukuman ta'zir berupa penetapan wasiat wajibah untuk anak hasil zina atas harta waris laki-laki yang menyebabkan kelahirannya. ${ }^{33}$ Wasiat wajibah dalam hal ini berupa penjatuhan kewajiban bagi laki-laki yang mengakibatkan lahirnya anak zina untuk berwasiat memberikan harta kepada anak hasil zina setelah yang bersangkutan meninggal dunia, ${ }^{34}$ sebagaimana yang diatur dalam kutipan Fatwa No.11 Tahun 2012 berikut:

[...] Pemerintah berwenang menjatuhkan hukuman ta'zir kepada lelaki pezina yang mengakibatkan lahirnya anak dengan mewajibkannya untuk:

a. $[\ldots]$

b. memberikan harta setelah ia meninggal melalui wasiat wajibah.

Perlindungan anak melalui wasiat wajibah adalah tindakan yang sepenuhnya merupakan kewenangan penguasa dan dalam praktik dilimpahkan pada hakim pengadilan agama melalui penjatuhan putusan atau penetapan yang memuat amar wasiat wajibah. Hal penting dalam wasiat wajibah adalah sifat wajib yang melekat pada lembaga wasiat ini dimana wasiat dikeluarkan bukan atas dasar keinginan pemilik harta atau pewasiat, melainkan dikeluarkan melalui putusan hakim. Sifat wajib yang melekat pada wasiat wajibah menghilangkan unsur ikhtiar bagi si pemberi wasiat dan munculnya unsur kewajiban melalui pandangan atau surat keputusan tanpa tergantung pada

\footnotetext{
31 Ketentuan hukum angka (5) Fatwa Majelis Ulama Indonesia Nomor 11 Tahun 2012 tentang Kedudukan Anak Hasil Zina dan Perlakuan Terhadapnya.

32 Ketentuan hukum angka (5) Fatwa Majelis Ulama Indonesia Nomor 11 Tahun 2012 tentang Kedudukan Anak Hasil Zina dan Perlakuan Terhadapnya.

33 Ibid

34 Lihat ketentuan umum angka (4) Fatwa Majelis Ulama Indonesia Nomor 11 Tahun 2012 tentang Kedudukan Anak Zina dan Perlakuan Terhadapnya.
} 
kerelaan orang yang berwasiat dan persetujuan penerima wasiat. ${ }^{35}$ Melalui penetapan wasiat wajibah ini, maka perlindungan hukum bagi anak hasil zina dapat dilakukan secara langsung tanpa harus menunggu inisiatif dari laki-laki yang mengakibatkan kelahirannya.

Berdasarkan hal-hal tersebut di atas, terlihat kontribusi Fatwa MUI No.11 Tahun 2012 dalam pengembangan hukum keluarga Islam di Indonesia secara khusus, dan hukum keluarga dalam sistem hukum nasional secara umum. Fatwa MUI No.11 Tahun 2012 telah meluruskan bias definisi dan kedudukan hukum anak yang lahir tanpa adanya perkawinan yang terjadi pasca Putusan MK No. 46/PUU-VIII/2010. Lebih jauh lagi, Fatwa MUI No.11/2016 secara komprehensif memberikan solusi pada pemerintah dan menegaskan secara rinci perlindungan hukum bagi anak yang lahir sebagai akibat perbuatan zina.

2. Kontribusi Fatwa MUI No. 11 Tahun 2012 sebagai Pertimbangan Hakim dalam Putusan Bidang Perkawinan di Pengadilan Agama

Fatwa MUI secara umum tidak dikhususkan kepada suatu golongan tertentu saja, dan tidak ada ketentuan yang mewajibkan penggunaannya dalam ranah litigasi. Penggunaan fatwa MUI No.11 Tahun 2012 dalam penyelesaian perkara di Pengadilan Agama tidak bersifat imperatif, melainkan diserahkan sepenuhnya dalam pertimbangan hakim saat mengadili perkara terkait. ${ }^{36}$ Ketentuan ini bersifat fakultatif, namun dalam praktik, Fatwa MUI No.11 Tahun 2012 digunakan oleh hakim di Pengadilan Agama sebagai pedoman dalam membantu menyusun putusan yang berkeadilan. Norma hukum materiil yang dikandung dalam Fatwa MUI No.11./2012 dianggap telah disusun secara komprehensif sesuai dengan prinsip hukum Islam, sehingga memenuhi syarat untuk digunakan sebagai sumber hukum Ijtihad.

Fatwa MUI No.11 Tahun 2012 dalam tataran praktik di Pengadilan Agama, sangat membantu hakim untuk menyusun pola pikir dan pertimbangan hukum yang berkaitan dengan kedudukan anak yang lahir tanpa adanya perkawinan kedua orang tuanya. Fatwa MUI No.11 Tahun 2012 telah mengakomodir norma hukum yang sudah ada dalam sistem hukum keluarga di Indonesia sebagaimana diatur dalam Undang-undang No. 1 Tahun 1974 tentang Perkawinan dan KHI, sekaligus juga meluruskannya sesuai ketentuan hukum Islam. ${ }^{37}$ Penelitian ini menemukan beberapa kedudukan Fatwa No.11/2012 dalam pertimbangan hukum yang digunakan oleh hakim Pengadilan Agama sebagai berikut:

\section{a. Fatwa MUI No.11 Tahun 2012 sebagai Pedoman Hakim}

Institusi MUI dalam lintasan sejarah pernah menjadi salah satu institusi yang ditetapkan oleh Undang-undang sebagai pembina lingkungan Peradilan Agama. Undang-undang No. 4 Tahun 2004 tentang Kekuasaan Kehakiman mengatur peran MUI dalam pembinaan Peradilan Agama ditegaskan bahwa : ${ }^{38}$

Mengingat sejarah perkembangan Peradilan Agama yang spesifik dalam sistem peradilan nasional, pembinaan terhadap badan Peradilan Agama dilakukan dengan memperhatikan saran dan pendapat menteri Agama dan majelis Ulama Indonesia.

\footnotetext{
35 Fatchur Rahman, 1981, Ilmu Waris, Al- Ma'arif, Bandung, hlm. 63.

36 Pendapat KRT. Drs. H. Ahmad Muhsin Kamaludiningrat dalam Focus Group Discussion Focus Group Discussion yang diselenggarakan di Yogyakarta, 27 Mei 2017.

37 Pendapat Drs.H. Nashruddin Salim, S.H., M.H., dan Latifah Setyawati, S.H., M.Hum. pada Focus Group Discussion di Yogyakarta, 27 Mei 201.

38 Alinea Keempat Penjelasan Umum Undang-Undang Nomor 4 Tahun 2004 tentang Kekuasaan Kehakiman (Lembaran Negara Republik Indonesia Tahun 2004 Nomor 8, Tambahan Lembaran Negara Republik Indonesia Nomor 4358).
} 
Melalui ketentuan ini, MUI mewujudkan perannya dalam bentuk memberikan peringatan, nasehat dan fatwa mengenai masalah keagamaan dan kemasyarakatan kepada masyarakat dan pemerintah dengan bijak (hikmah) dan menyejukkan. ${ }^{39}$ Kedudukan MUI sebagai pembina Pengadilan Agama kemudian berubah setelah pemberlakuan Undang-undang No. 48 Tahun 2009 tentang Kekuasaan Kehakiman. Undang-undang ini tidak lagi mencantumkan kedudukan MUI dalam pembinaan Peradilan Agama. Dalam hal ini tampak MUI tidak lagi memiliki ikatan dengan Pengadilan Agama secara yuridis formal. Namun demikian, pembinaan MUI masih tetap diperlukan dalam menguatkan lembaga Pengadilan Agama terutama dalam hal: ${ }^{40}$

Pertama, mendorong masyarakat menuju budaya hukum syariah sehingga masyarakat dengan penuh kesadaran memahami, menghayati, dan mantaati hukum-hukum syariah Islam secara kaffaah. Kedua, mendorong masyarakat untuk menyelesaikan sengketa mereka dalam kehidupan sehari-hari sesuai tuntunan syariah, yakni menggunakan standar hukum syariah dan melalui lembagalembaga syariah, termasuk di dalamnya Badan Arbitrase Syariah Nasional dan Peradilan Agama yang merupakan satusatunya peradilan syariah Islam di Indonesia. Ketiga, mengawal dan menegakkan Peradilan Agama sebagai peradilan syariah Islam agar tidak menyimpang dari doktrin dan ruh syariah. Berdasarkan hal tersebut di atas, maka hakim Pengadilan Agama sampai saat ini masih menggunakan Fatwa MUI terkait sebagai rujukan dalam proses litigasi khususnya pengambilan putusan akhir atas sengketa yang diajukan.

Khusus untuk fatwa MUI No.11 Tahun 2012, dalam perspektif hakim Pengadilan Agama, fatwa memang tidak mengikat secara yuridis formil dalam artian tidak ada kewajiban bagi hakim untuk menggunakan fatwa dimaksud dalam proses litigasi. Bagi hakim, kedudukan fatwa MUI No.11 Tahun 2012 sama seperti kitab-kitab fiqih lainnya. Fatwa MUI No.11 Tahun 2012 tidak wajib untuk digunakan sebagai dasar pertimbangan, namun dapat menjadi pedoman dan panduan bagi hakim Pengadilan Agama dalam menyusun dasar pertimbangan. ${ }^{41}$ Sebagai pedoman, fatwa MUI dipandang sebagai considered legal opinion atau pendapat hukum yang berdasarkan pertimbangan..$^{42}$ Perumusan norma hukum dalam Fatwa MUI dimaksudkan untuk memberikan pendapat hukum kepada anggota masyarakat tentang tindakan apa yang benar menurut pandangan hukum Islam. ${ }^{43}$ Khusus untuk fatwa MUI No.11 Tahun 2012, fatwa ini telah berhasil menjelaskan ketentuan prinsip hukum Islam tentang status dan kedudukan hukum anak sehingga dapat digunakan sebagai pedoman dalam menyelesaikan kasus hukum kongkrit yang diajukan ke Pengadilan Agama.

\section{b. Fatwa MUI No.11 Tahun 2012 sebagai Pengisi Kekosongan Hukum}

Sebagaimana yang telah dijelaskan di atas, sampai dengan saat ini belum ada regulasi yang mengatur secara khusus tentang status dan kedudukan hukum anak yang lahir dari perbuatan zina. Ketentuan hukum tentang status anak yang selama ini diatur melalui Undang-Undang No. 1 Tahun 1974 tentang Perkawinan dan Kompilasi Hukum Islam tidak menggunakan istilah anak hasil zina secara spesifik. Keduanya menempatkan anak hasil zina dalam kategori anak yang lahir di luar perkawinan dan membatasi hubungan keperdataan anak dalam kelompok ini dengan laki-laki yang mengakibatkan kelahirannya. Pada posisi inilah kemudian Fatwa MUI No.11 Tahun 2012 berperan dalam mengisi kekosongan hukum tersebut.

\footnotetext{
39 Pasal 6 Pedoman Dasar Majelis Ulama Indonesia

40 Mukti Arto, 2012, Peradilan Agama dalam Sistem Ketatanegaraan Indonesia Kajian Historis, Filosofis, Ideologis, Politis, Yuridis, Futuristis, Pragmatis, Pustaka Pelajar, Yogyakarta, hlm. 199.

$41 \quad$ Pendapat Drs.H. Nashruddin Salim, S.H., M.H. pada Focus Group Discussion di Yogyakarta, 27 Mei 2011.

42 Zafrullah Salim, "Kedudukan Fatwa dalam Negara Hukum Republik Indonesia", dalam Puslitbang lektur dan Khazanah Keagamaan, 2012, Fatwa Majelis Ulama Indonesia (MUI) dalam Perspektif Hukum dan Perundang-Undangan, Badan Litbang dan Diklat Kementerian Agama, Jakarta, hlm. 587.

43 Ibid.
} 
Fatwa secara umum berperan untuk mentransformasikan makna hukum Islam yang bersifat umum ke dalam kasus konkrit. Dikaitkan dengan materi hukum yang terkandung di dalamnya, fatwa MUI No.11 Tahun 2012 merumuskan secara rinci tentang kedudukan hukum anak hasil zina, hak-hak yang melekat padanya, serta pedoman bagi pemerintah dalam melindungi hak-hak tersebut. Rumusan ini menjadi salah satu pedoman yang membantu hakim saat terjadi kekosongan hukum. Sampai dengan dikeluarkannya peraturan lain yang mengikat, fatwa MUI No. 11 Tahun 2012 merupakan sumber hukum bagi pertimbangan hakim dalam menyelesaikan sengketa bidang hukum keluarga khususnya dalam menentukan status dan kedudukan hukum anak yang lahir dari hasil zina.

\section{c. Fatwa MUI No.11 Tahun 2012 sebagai Sumber Hukum Materiil}

Sumber hukum materiil dalam studi ilmu hukum diartikan sebagai sumber hukum berupa keyakinan individu dan pendapat umum yang menjadi determinan materiil membentuk dan menentukan isi hukum. ${ }^{44}$ Dalam hubungannya dengan sumber hukum dalam lingkup agama, maka pengamalan norma-norma agama dapat digunakan sebagai sumber hukum materiil bagi masyarakat. ${ }^{45}$

Praktik penggunaan sumber hukum dalam lingkup agama sendiri sudah dilakukan dalam sistem hukum nasional Indonesia. Pada periode awal pembentukan Pengadilan Agama dan Mahkamah Syar'iyah, hakim pada pengadilan tersebut sudah dianjurkan untuk menggunakan 13 (tiga belas) kitab fiqih sebagai pedoman hakim dalam memeriksa perkara ${ }^{46}$ Sejalan dengan hal tersebut, perumusan Kompilasi Hukum Islam yang saat ini digunakan sebagi sumber hukum materiil di Pengadilan Agama juga merupakan bentuk penggunaan ketentuan agama sebagai sumber hukum materiil.

Hal yang sama juga berlaku pada fatwa MUI No.11 Tahun 2012. Walaupun tidak ada kewajiban untuk menggunakan fatwa ini, namun dalam praktik fatwa MUI No.11 Tahun 2012 digunakan sebagai sumber hukum untuk merumuskan dasar pertimbangan hakim dalam lingkup sengketa bidang hukum keluarga. Dalam kedudukannya sebagai sumber hukum materiil, fatwa MUI No.11 Tahun 2012 digunakan sebagai pelengkap atas Undang-undang No. 1 Tahun 1974 tentang Perkawinan dan Kompilasi Hukum Islam. ${ }^{47}$ Melalui penggunaan fatwa MUI No.11 Tahun 2012, hakim dapat menjatuhkan putusan yang komprehensif dan dapat diterapkan dalam kasus konkrit.

Berdasarkan penjelasan di atas, maka fatwa MUI No.11 Tahun 2012 memiliki kedudukan penting dalam hukum keluarga Islam di Indonesia. Secara materiil, fatwa MUI No.11 Tahun 2012 berperan penting dalam pengembangan norma hukum keluarga Islam guna mengikuti dinamika masyarakat, sedangkan secara formil, fatwa MUI No.11 Tahun 2012 merupakan salah satu dasar hukum yang digunakan oleh hakim di Pengadilan Agama dalam menyelesaikan kasus konkrit.

\section{Kesimpulan}

Berdasarkan kajian yang telah dilakukan, penelitian ini menyimpulkan 2 (dua) bentuk kontribusi Fatwa MUI No. 11 Tahun 2012 tentang Kedudukan Anak Hasil Zina dan Perlakuan Terhadapnya dalam Hukum Keluarga Islam di Indonesia yaitu:

1. Kontribusi dalam pengembangan hukum keluarga islam di Indonesia, yaitu:

a. Sebagai klarifikasi dan
penjelasan atas Putusan MK
Nomor 46/PUU-VIII/2010;
b. Sebagai penegasan larangan
berzina;
c. Sebagai rekomendasi bagi
pemerintah; dan

44 Moh. Saleh Djindang, 1989, Pengantar dalam Hukum Indonesia, Sinar Harapan, Jakarta, hlm. 3.

45 Lihat Bagir Manan, 1987, Konvensi Ketatanegaraan, Armico, Bandung, hlm. 13.

46 Surat Edaran Kepala Biro peradilan Agama Departemen Agama RI Nomor B/I/735 tentang Pelaksanaan Peraturan Pemerintah Nomor 45 Tahun 1957 tentang Pembentukan Pengadilan Agama/Mahkamah Syar'iyah di Luar Jawa-Madura.

47 Pendapat Latifah Setyawati, S.H., M.Hum., pada Focus Group Discussion di Yogyakarta, 27 Mei 2017. 

d. Sebagai bentuk perlindungan hukum bagi anak

2. Kontribusi dalam pertimbangan hakim dalam putusan bidang perkawinan di Pengadilan Agama: a. Sebagai pedoman hakim;

b. Sebagai pengisi kekosongan hukum; dan

c. Sebagai sumber hukum materiil.

\section{DAFTAR PUSTAKA}

\section{A. Buku}

Amin, Ma'ruf, 2008, Fatwa dalam Sistem Hukum Islam, Elsas, Jakarta.

Adams, Wahiduddin, 2004, Pola Penyerapan Fatwa Majelis Ulama Indonesia (MUI) dalam Peraturan Perundang-undangan 1975-1997, Departemen Agama Republik Indonesia, Jakarta.

Arto, Mukti, 2017, Penemuan Hukum Islam Demi Mewujudkan Keadilan Buku Kesatu Membangun Sistem Peradilan Berbasis Perlindungan Hukum dan Keadilan, Pustaka Pelajar, Yogyakarta.

Djindang, Moh. Saleh, 1989, Pengantar dalam Hukum Indonesia, Sinar Harapan, Jakarta.

Mahkamah Agung, 2013, Pedoman Pelaksanaan Tugas dan Administrasi Peradilan Agama Buku II, Dirjen Peradilan Agama Mahkamah Agung, Jakarta.

Majelis Ulama Indonesia, 1975, Pedoman Dasar Majelis Ulama Indonesia, Majelis Ulama Indonesia, Jakarta.

Manan, Bagir, 1987, Konvensi Ketatanegaraan, Armico, Bandung.

Mudzhar, Muhammad Atho, 1993, Fatwa-fatwa Majelis Ulama Indonesia Sebuah Studi tentang Pemikiran Hukum Islam di Indonesia 1975-1988,INIS, Jakarta.

Puslitbang Lektur dan Khazanah Keagamaan, 2012, Fatwa Majelis Ulama Indonesia (MUI) dalam Perspektif Hukum dan Perundangundangan, Badan Litbang dan Diklat Kementerian Agama, Jakarta.

Santoso, Topo, 2003, Membumikan Hukum Pidana
Islam di Indonesia Penegakan Syariat dalam Wacana dan Agenda, Gema Insani Press, Jakarta.

\section{B. Artikel Jurnal}

Musawwamah, Siti, "Pro-kontra atas Putusan Mahkamah Konstitusi tentang Pengesahan Hubungan Keperdataan Anak Luar Kawin dengan Ayah Biologis", Nuansa, Vol.10, No.1, Januari-Juni, 2013.

\section{Makalah}

IKAHI Cabang Pengadilan Tinggi Agama Semarang, "Rumusan Hasil Diskusi tentang Kedudukan Anak yang Lahir di Luar Perkawinan pasca Putusan MK Nomor 46/ PUU-VIII/2010 tanggal 17 Februari 2012, Makalah Rumusan Hasil Diskusi, Diskusi IKAHI Cabang Pengadilan Tinggi Agama Semarang, Semarang, Rabu 11 April 2012.

\section{Internet}

Detiknews, "MUI Nilai Keputusan MK Soal Status Anak di Luar Nikah Overdosis", http:// news.detik.com/berita/1866192/mui-nilaikeputusan-mk-soal-status-anak-di-luarnikah-overdosis, diakses 24 Maret 2017.

\section{E. Peraturan Perundang-Undangan}

Undang-Undang Nomor 1 Tahun 1974 tentang Perkawinan (Lembaran Negara Republik Indonesia Tahun 1974 Nomor 1, Tambahan Lembaran Negara Nomor 3019).

Undang-Undang Nomor 4 Tahun 2004 tentang 
Kekuasaan Kehakiman (Lembaran Negara Republik Indonesia Tahun 2004 Nomor 8, Tambahan Lembaran Negara Republik Indonesia Nomor 4358).

Undang-Undang Nomor 48 Tahun 2009 tentang Kekuasaan Kehakiman (Lembaran Negara Republik Indonesia Tahun 2009 Nomor 157, Tambahan Lembaran Negara Republik Indonesia Nomor 5076).

Undang-Undang Nomor 23 Tahun 2002 tentang Perlindungan Anak (Lembaran Negara Nomor 109 Tahun 2002, Tambahan Lembaran Negara Nomor 4235).

Undang-Undang Nomor 35 Tahun 2014 tentang Perubahan atas Undang-Undang No. 23 Tahun 2002 tentang Perlindungan Anak (Lembaran Negara Nomor 297 Tahun 2014, Tambahan Lembaran Negara Nomor 5606).

Instruksi Presiden Republik Indonesia Nomor 1 Tahun 1991 tentang Penyebarluasan Kompilasi Hukum Islam (Lembaran Lepas Sekretariat Negara Tahun 1991).
Fatwa Majelis Ulama Indonesia Nomor 11 Tahun 2012 tentang Kedudukan Anak Hasil Zina dan Perlakuan Terhadapnya.

Surat Edaran Kepala Biro peradilan Agama Departemen Agama RI Nomor B/I/735 tentang Pelaksanaan Peraturan Pemerintah No. 45 Tahun 1957 tentang Pembentukan Pengadilan Agama/Mahkamah Syar'iyah di Luar Jawa-Madura.

\section{F. Lain-Lain}

Putusan Mahkamah Konstitusi Nomor 46/PUUVIII/2010, 17 Februari 2012.

Pendapat KRT. Drs. H., Ahmad Muhsin Kamaludiningrat, Drs. H. Nashruddin Salim, S.H., M.H., Ummu Hafizhah, S.H.I., S.E., M.A., dan Latifah Setyawati, S.H., M.Hum. pada Focus Group Discussion di Yogyakarta, 27 Mei 2017. 